\title{
TOWARDS CREATIVE FOREIGN LANGUAGE TEACHING: THE THEORY OF MULTIPLE INTELLIGENCES IN USE
}

\section{SUMMARY}

Introduction. The article provides a conceptual setting for conscious teaching whereby classroom activities are referred to the principles of MIT. It also advocates an experimental insight into foreign language teaching where both a teacher and a student are encouraged to explore, discover and practice their multiple intelligences while teaching and mastering foreign languages. Additionally, practical implications of MIT for FLT are discussed and illustrated by a few examples of the activities designed in the framework of the theory.

The Aim of the Study. To establish a new perspective on both effective and creative foreign language teaching (FLT) in the framework of Howard Gardner's Theory of Multiple Intelligences (MIT).

Methods: examination of MIT, deductive/inductive analysis

Results. Foreign language students benefit from FLT methods with a reference to MIT which, being learner-centred, cater for an individual student's needs and preferences, provide a meaningful context for FLT and, consequently, increase the level of students' motivation for learning foreign languages.

Conclusions. Foreign language teachers should experiment with MIT for a number of reasons: firstly, to establish a student-oriented insight into teaching; secondly, to provide a meaningful context for teaching; and finally, to increase the level of students' motivation to learn a foreign language.

Keywords: foreign language teaching (FLT), theory of Multiple Intelligences (MIT), intelligences, verbal/linguistic intelligence, experimental learning/teaching, learner-centred teaching, individualized instruction, independent learning, success

\section{INTRODUCTION}

In 1983 Howard Gardner started a revolution in the field of cognitive science introducing the theory of multiple intelligences (MIT) (Gardner, 1983, 1999), and advocating a learner-based philosophy which has become known as "an in increasingly popular approach to characterizing the ways in which learners are unique and to developing instruction to respond to this uniqueness" (Richards \& Rodgers, 2001). By doing so, Gardner not only challenged the unitary concept of intelligence but also criticized the school systems prevailing so far. Consequently, Gardner's MIT invited educators to exploit the holistic nature of each learner and establish a learner-centred way of teaching with the recognition of each learner's intelligence profile so that teaching became a creative and meaningful enterprise.

\section{THE AIM OF THE STUDY}

To establish a new perspective on both effective and creative foreign language teaching (FLT) in the framework of Howard Gardner's Theory of Multiple Intelligences (MIT).

MATERIALS AND METHODS

\section{THE THEORY OF MULTIPLE INTELLIGENCES VERSUS TEACHING}

We should not take care not to make the intellect our god. It has, of course, powerful muscles, but no personality. It cannot lead, it can only serve. 
Teaching is not filling up a pail, it is lighting a fire.

William Butler Yeats

Every child has, at birth, a greater potential than Leonardo Da Vinci ever used.

Glenn Doman

The advent of a humanistic approach towards teaching in the $60 \mathrm{~s}$ of the $20^{\text {th }}$ century brought a new insight into the nature of foreign language teaching replacing conventional methods by non-conventional, student-cantered and individualized ways of teaching. The Classical Method as well as the Grammar Translation Method gave way to a number of innovative methods which emphasized the importance of perceiving each student as a "whole person" with their own unique psychological background and physical environment. The recognition of individual learners' affective factors was to make the process of learning efficient. A range of non-conventional methods such as The Silent Way, Total Physical Response, Community Language Learning, Suggestopedia, etc. advocated a learner-based instruction with a low-stress factor and aimed at quick and successful mastery of foreign languages.

What is the success of a foreign language learner determined by? Clearly, it is determined by many factors - both extrinsic and intrinsic - such as motivation, physical conditions, intelligence, learning styles, gender, aptitude and age. Rod Ellis (Ellis, 1985) claims that the success of a foreign language learner relies on the combination of "an academic ability with some cognitive qualities", both of which constitute necessary components of the so-called general intelligence. Therefore, intelligence is closely connected with successful foreign language teaching and learning.

The word "intelligence" comes from the Latin verb intellegere and means "to understand". Generally, for most of us intelligence seems to have some mystique quality and few people approach IQ tests with enthusiasm feeling that they tend to evaluate intelligence too narrowly limiting it mostly to the ability to think logically and visualize things. What is more, for years intelligence had been perceived as a unitary concept defined operationally as the ability to answer IQ test questions. One of the researchers, who challenged the unitary concept of intelligence was Howard Gardner, a Harvard psychologist researching brain injuries. Criticizing the narrow view on intelligence, he emphasized its pluralistic nature and offered a new insight into the definition of intelligence (Gardner, 1983):

To my mind, a human intellectual competence must entail a set of skills of problem solving - enabling the individual to resolve genuine problems or difficulties that he or she encounters and, when appropriate, to create an effective product - and must also entail the potential for finding or creating problems - thereby laying the groundwork for the acquisition of new knowledge (Emphasis in original).

Gardner introduced his theory of multiple intelligences in his book entitled "Frames of Mind" published in 1983. In the book he pointed out that I. Q. tests tend to measure primarily the so-called basic skills - logical/mathematical and spatial abilities - thus offering a limited score of the individuals whose strengths do not lie in these basis skills (Gardner, 1983). Gardner also claimed that school systems of education focus mainly on the basic skills neglecting other skills and talents exhibited by children. He claimed that humans have evolved an ability to carry out several types of intelligences (Gardner, 1983). 
Table 1. Howard Gardner's 8 types of multiple intelligences

\begin{tabular}{|l|l|}
\hline 1.Verbal/linguistic intelligence & $\begin{array}{l}\text { Involves reading, writing and speaking and is respectively } \\
\text { exercised through practising reading, writing, speaking and } \\
\text { listening skills. }\end{array}$ \\
\hline 2.Logical-mathematical intelligence & $\begin{array}{l}\text { Involves abstract thinking, classifying, sequencing and computing } \\
\text { skills and is exercised through mathematics, logic games and } \\
\text { puzzles. }\end{array}$ \\
\hline 3. Musical intelligence & $\begin{array}{l}\text { Involves understanding, composing, conducting music and dancing } \\
\text { and is exercised through singing, dancing, playing and interpreting } \\
\text { music. }\end{array}$ \\
\hline 4. Spatial intelligence & $\begin{array}{l}\text { Involves good visual perception of the environment and the } \\
\text { orientation in space and is exercised through practising the graphic } \\
\text { and plastic arts, doing spatial tasks and practising imagination. }\end{array}$ \\
\hline 5. Bodily kin esthetic intelligence & $\begin{array}{l}\text { Involves physical coordination, dexterity and a good grasp of } \\
\text { motor skills and is exercised through active sports and games. }\end{array}$ \\
\hline 7. Intrapersonal intelligence & $\begin{array}{l}\text { Involves the ability to communicate well and understand other } \\
\text { people and is exercised through cooperative, group and pair work. }\end{array}$ \\
\hline 8. Naturalistic intelligence & $\begin{array}{l}\text { Involves understanding one's inner world of emotions, the } \\
\text { ability to control them and express them and is exercised through } \\
\text { reflection, journal writing and imaginative games. }\end{array}$ \\
\hline & $\begin{array}{l}\text { Involves understanding Nature as well as the ability to observe, } \\
\text { classify and categorize plants and animals and is exercised through } \\
\text { exploring and studying Nature. }\end{array}$ \\
\hline
\end{tabular}

Gardner firmly believes that the eight intelligences are independent being developed at different times and to different levels in different individuals. He also claims that they are related: each intelligence does influence and enhance the level of other intelligences (Gardner, 1998). Consequently, by practising one's strong intelligences, an individual may enhance the level of his/her weak intelligences, which implies a range of new possibilities for educators.

Gardner's introduction of MIT has had an enormous impact on educational systems. Starting from 1983, his ideas have been enthusiastically introduced into the system of education especially in North America. MIT has gained propagators all around the world who continue experimenting with it in the classroom for it is "an increasingly popular approach to characterizing the ways in which learners are unique and to developing instruction to respond to this uniqueness" (Richards, Rogers, 2001).

\section{THE IMPLICATIONS OF MIT FOR SCHOOL SYSTEMS OF EDUCATION}

Traditional school systems are designed and many teachers teach as if all learners were the same. Gardner points out that school systems often focus on a narrow range of intelligences emphasizing verbal/linguistic and logical/mathematical skills (Gardner, 1983). This practice results in imposing the reputation of being a weaker and less intelligent pupil if a student does not do well in the basic skills. Consequently, a learner strives through the school years with a hatred for mathematics and language lessons perceiving oneself as a failure. In the light of the prevailing schools' uniformity, MIT brings a positive message focusing on the strongest points of a student so that nobody is seen as a failure. In other words, Gardner offers a new insight into the system of education where the major task of an educator is to encourage children to explore and exercise all types of their intelligences. He also points out the social advantages of his theory put into practice (Gardner, 1993): 
It is of the utmost importance that we recognise and nurture all the varied human intelligences, and all of the combinations of the intelligences. We are all so different largely because we all have different combinations of intelligences. If we recognize this, I think we will have at least a better chance of dealing appropriately with the many problems that we face in the world. If we can mobilize the spectrum of human abilities, not only will people feel better about themselves and more competent; it is even possible that they will also feel more engaged and better able to join the rest of the world community in working for the broader good.

Thus, creating a rich, stimulating and active environment from the beginning of school education will result in generations of healthier, happier and brighter people (Gardner, 1999):

I want my children to understand the world, but not just because the world is fascinating and the human mind is curious. I want them to understand it so that they will be positioned to make it a better place. Knowledge is not the same as morality, but we need to understand if we are to avoid past mistakes and move in productive directions. An important part of that understanding is knowing who we are and what we can do... Ultimately, we must synthesize our understandings for ourselves. The performance of understanding that try matters are the ones we carry out as human beings in an imperfect world which we can affect for good or for ill.

Obviously, the advantages of the MIT as used in the classroom are many for it helps teachers to create a more personalized and diversified syllabus where instruction is matched to learning styles (Gardner, 1993):

"Seven kinds of intelligence would allow seven ways to teach, rather than one. And powerful constraints that exist in the mind can be mobilized to introduce a particular concept (or whole system of thinking) in a way that children are most likely to learn it and least likely to distort it. Paradoxically, constraints can be suggestive and ultimately freeing."

Another advantage of MIT is that by focusing on success rather than failure it helps to create a positive atmosphere thus enhancing both extrinsic and intrinsic motivation of learners. What is more, teachers are encouraged to broaden their workshop by assisting in helping students become empowered learners (Kornhaber, 2001):

"[...] the theory validates educators' everyday experience: students think and learn in many different ways. It also provides educators with a conceptual framework for organizing and reflecting on curriculum assessment and pedagogical practices. In turn, this reflection has led many educators to develop new approaches that might better meet the needs of the range of learners in their classrooms."

Finally, with the use of MIT concepts classes gain a spirit of adventure and discovery where both teachers and students are encouraged to experiment. Certainly, teaching concepts, when related to MIT, tend to produce self-efficient and motivated learners, who perceive the process of their education as being creative and dynamic. What is more, the teachers incorporating their teaching syllabus into the MIT concepts will enjoy a never ending challenge of creative and experimental teaching.

\section{THE THEORY OF MULTIPLE INTELLIGENCE IN FOREIGN LANGUAGE TEACHING}

In recent years there has been great research done in the field of foreign language teaching methodology. Much emphasis has been given to the research of different learning styles and learners' profiles. Reid mentions some of the major directions in this research: multiple intelligences, perceptual learning styles, field dependence/independence, analytic/global learning styles and reflective/impulsive learning styles (Ride, 1999). Learners' greater awareness of their own styles of learning has resulted in a more effective foreign language teaching making them realise their own responsibility for the outcome: "higher interest and motivation in the learning process, increased student responsibility for their own learning, and greater classroom community. These are affective changes, and the changes have resulted in more effective learning" (Ride, 1999). 
Although Gardner does not make a direct reference to foreign language teaching, MIT has been successfully used in FLT. This experience has brought successful results with students of different nationalities, ages and abilities, and has been accepted with much enthusiasm by their teachers and parents. When used in a foreign language classroom, it allows each student to draw from their own strengths to approach learning and creates an opportunity to learn a foreign language in a meaningful context wherein verbal intelligence is practised in combination with other intelligences.

According to MIT, a good language learner is a learner who has a well-developed verbal/ linguistic intelligence which implies that some learners are better-equipped for learning a foreign language. On the other hand, those who cannot boast about their verbal intelligence can still enjoy and succeed in language learning because it can be supported by using their musical, bodily-kinaesthetic, interpersonal, intrapersonal, mathematical and naturalistic abilities since "they constitute frames for working on the same linguistic content" (Arnold \& Fonseca, 2004).

Certainly, many foreign language teachers find MIT a perfectly acceptable addition to every school curriculum and an invaluable tool for the transformation of education: "From a teaching point of view, it is [...] important to recognise the fact that learners are in fact different and therefore learn differently. Only in doing so can teachers full encourage their learners to try harder and at the same time make the learning environment as meaningful and enjoyable as possible for the parties involved" (Palmberg, 2002). Hopefully, more and more foreign language teachers will want to face the challenge of using MIT during their lessons for it is absolutely worth the effort and time spent on the preparation of the activities based on MI.

\section{RESULTS}

\section{FLT ACTIVITIES DESIGNED IN THE FRAMEWORK OF MIT}

Below are given sample exercises designed in the framework of MIT to be used during foreign language lessons with students of different age and level. They aim at practising language skills through the use of different types of intelligences. Therefore, they cater for different types of learners' intelligence profiles allowing each student to base their foreign language practice on the profile they are good at and therefore, improve their motivational drive.

\section{"My journal"}

The activity aims at developing verbal-linguistic and intrapersonal intelligences. The focus is on developing the ability to identify and express one's thoughts and emotions. The activity can be used even with post-beginners. It aims at developing free-writing.

\section{Procedure:}

Students are asked to keep a diary where they are to comment on their everyday experiences in the classroom. From time to time a teacher collects diaries and comments on what each student has written in the diary.

\section{"The place I live in"}

The activity aims at developing visual-spatial and interpersonal intelligences. Being a hands-on activity, it also promotes a cooperative learning. The focus is on the description of the place the students live in with the emphasis on urban vocabulary.

\section{Procedure:}

Students are asked to bring cardboard, boxes, brightly-coloured paper, glue, etc. They work in groups. Using the materials they have brought, they have to make a building/buildings they have visited/seen in their town/city.

When they finish, students get together to build a single model of their city/town placing the buildings they have built in the correct street. When the model of the city/town is ready, students name the streets. Finally, they describe the town/city in English.

"Who are you in the mirror?"

The activity aims at developing intrapersonal and interpersonal intelligences. 
The goal is to help students to identify feelings and express emotions adequately.

Procedure:

Students are asked to bring mirrors into the classroom. The teacher uses flashcards to show people's faces expressing different emotions. Students have to identify the feeling or emotions and then imitate these emotions in the mirrors.

\section{CONCLUSIONS}

MIT becomes a perfect ingredient to a foreign language curriculum for it caters for learners' individual differences and advocates an individual approach towards FLT enabling both the teacher and learner to master a foreign language in an efficient, meaningful and creative way. Therefore, foreign language teachers should experiment with MIT for a number of reasons: firstly, to establish a student-oriented insight into teaching; secondly, to provide a meaningful context for teaching; and finally, to increase the level of their students' motivation to learn a foreign language.

\section{REFERENCES}

1. Arnold, J., Fonseca, C. (2004) Multiple Intelligence Theory and Foreign Language Learning: A Brain-based Perspective. International Journal of English Studies, Vol. 4 (1), p. 119-136. http://www.um.es/engphil/ijes (04.09.2009.)

2. Ellis, R. (1985) Understanding Second Language Acquisition. Oxford: Oxford University Press, p. 5-6.

3. Gardner, H. (1983) Frames of Mind. The Theory of Multiple Intelligences. New York: Basic Books. p. 54-61.

4. Gardner, H. (1993) Frames of Mind. The Theory of Multiple Intelligences, $2^{\text {nd }}$ edition. New York: Basic Books, p. xxiii (Foreword), p. 8-13.

5. Gardner, H. (1998) A Reply to Perry D. Klein's Multiplying the Problems of Intelligence by Eight. Canadian Journal of Education, No 23(1), p. 96-102.

6. Gardner, H. (1999) Intelligence Reframed. Multiple Intelligences for the $21^{\text {st }}$ Century. New York: Basic Books, p. 183.

7. Kornhaber, M. L. (2001) Howard Gardner. In: J. A. Palmer (Ed.) Fifty Modern Thinkers on Education. From Piaget to the Present. London: Routledge, 276 p.

8. Palmberg, R. (2002) Catering for Multiple Intelligences - a Foreign Language Lesson Plan Involving Occupation. http://www.eltnewsletter.com/back/January2002/art852002.htm (04.09.2009.)

9. Richards, J., Rogers, T. (2001) Approaches and Methods in Language Teaching. Cambridge: Cambridge University Press, 123 p.

10. Ride, J. (1999) Affect in the Classroom: Problems, Politics, Pragmatics. In: J. Arnold (Ed.) Affect in Language Learning. Cambridge: Cambridge University Press, p. 297-306.

$\mathrm{PhD}$ (general linguistics) Renata Botwina

Tutor at the Higher School of Pedagogy in Warsaw of the Society of Public Knowledge in Warsaw Address: ul. Racławicka 131/6A, 02-117 Warsaw, Poland

Mob. phone: +48662247836

E-mail: renatajermolovic@wp.pl 